\title{
The Influence of Perceptions of Accreditation, Cost of Education, and Promotion on the Decision of Prospective Students to Pursue Postgraduate Studies at Universitas Harapan Medan
}

\author{
Sudartono Phannoto (Corresponding author) \\ Faculty of Business Economics, Universitas Harapan Medan \\ PO Box 20152, Medan, North Sumatra, Indonesia \\ Tel: 813-7724-8860Ｅ-mail: sudartonophannoto@gmail.com
}

Received: May 16, 2019 Accepted: June 17, 2019 Published: June 27, 2019

doi:10.5296/jad.v5i3.14991ＵRL: https://doi.org/10.5296/jad.v5i3.14991

\begin{abstract}
Universitas Harapan Medan is a leading university in Medan with four faculties divided into fourteen study programs consisting of three vocational programs, ten undergraduate programs, and a postgraduate program.

This study aimed to empirically examine the influence of perceptions of accreditation, cost of education, and promotion on the decision of prospective students. It used a quantitative approach. The population and samples were 227 and 145 people respectively. The types of data used were primary and secondary data. The data collection techniques used were questionnaires, interviews, literature review, and document review. Tests carried out in this study were validity and reliability tests, classical assumption tests including normality test, multicollinearity test, and heteroscedasticity test, hypothesis tests including $\mathrm{F}$ test and $\mathrm{t}$ test, multiple linear regression analysis, and coefficient of determination $\left(\mathrm{R}^{2}\right)$. The result of multiple linear regression was $\mathrm{Y}=3.882+0.294 \mathrm{X}_{1}+0.027 \mathrm{X}_{2}+0.584 \mathrm{X}_{3}$.

In this study, the result also indicated that $62.8 \%$ of the Decision of Prospective Students at Universitas Harapan Medan were influenced by Accreditation $\left(\mathrm{X}_{1}\right)$, Cost of Education $\left(\mathrm{X}_{2}\right)$, and Promotion $\left(\mathrm{X}_{3}\right)$, while the remaining $37.2 \%$ were influenced by other factors not being examined.
\end{abstract}




\section{Macrothink}

Keywords: Accreditation, cost of education, promotion, decision of prospective students, and postgraduate

\section{Introduction}

In line with the rapid economic development, every company is required to have reliable human resources. Therefore, education is one of the dominant alternatives to create competitive human resources. The importance of quality education is very much realized by educational institutions as well as prospective students in considering which university to choose. As a leading university, Universitas Harapan Medan needs to identify the factors that influence prospective students' decisions in choosing a university and then take the right strategy to convince them in order to keep it in existence.

This research began with a phenomenon that occurred in the postgraduate program in Management of Faculty of Business Economics of Universitas Harapan Medan. The finding was the number of postgraduate students was getting fewer extremely within 5 years.

Table 1. Number of Undergraduate Alumni and Postgraduate Students

\begin{tabular}{|c|c|c|c|c|c|c|c|c|c|}
\hline \multicolumn{5}{|c|}{ Undergraduate Alumni } & \multicolumn{5}{|c|}{ Postgraduate Students } \\
\hline $\begin{array}{l}\text { Graduation } \\
\text { Year }\end{array}$ & Mana. & Acco. & Total & $\begin{array}{l}\Delta \\
(\%)\end{array}$ & $\begin{array}{l}\text { Admission } \\
\text { Year }\end{array}$ & Alumni & Non-alumni & Total & $\begin{array}{l}\Delta \\
\%)\end{array}$ \\
\hline $2012-2013$ & 187 & 190 & 377 & - & $2013-2014$ & 3 & 24 & 27 & - \\
\hline $2013-2014$ & 186 & 242 & 428 & 14 & 2014-2015 & 6 & 22 & 28 & 4 \\
\hline 2014-2015 & 205 & 185 & 390 & -9 & $2015-2016$ & 5 & 13 & 18 & -36 \\
\hline $2015-2016$ & 169 & 167 & 336 & -14 & 2016-2017 & 1 & 6 & 7 & -61 \\
\hline 2016-2017 & 131 & 155 & 286 & -15 & $2017-2018$ & 2 & 2 & 4 & -43 \\
\hline
\end{tabular}

Source: FEB of Universitas Harapan Medan, 2018 (Data Processed).

The table above shows the number of undergraduate alumni in the last five years has fluctuated. However, the decline was just around $-6 \%$ per year. It was at least still in the hundreds. While the number of postgraduate students that enrolled each year had decreased severely up to approximately $-34 \%$ per year, even though there had been this program since 2005 (thirteen years ago). Such a huge decrease was certainly caused by many factors. Some of the factors might be Accreditation, Cost of Education, and Promotion.

Accreditation was chosen due to its importance in gaining the number of students in a university. It was in line with the research conducted by Bahri Kamal and Ghea Dwi Rahmadiane (2017) which stated: "Accreditation of the study program is the most influential variable on the decisions made by students in choosing Accounting study program at Politeknik Harapan Bersama." 


\section{Macrothink}

Table 2. Accreditation of Master in Management Programs in Medan

\begin{tabular}{llll}
\hline Higher Education & Accreditation & Year of Decree & Expiry Date \\
\hline Sekolah Tinggi Ilmu Ekonomi Informasi Teknologi dan & C & 2013 & $22-11-2018$ \\
Bisnis & & & \\
Universitas Darma Agung & B & 2014 & $02-05-2019$ \\
Universitas Harapan Medan & C & 2015 & $23-05-2020$ \\
Universitas HKBP Nomensen & B & 2014 & $14-11-2019$ \\
Universitas Islam Sumatera Utara & B & 2016 & $08-09-2021$ \\
Universitas Muhammadiyah Sumatera Utara & B & 2016 & $20-10-2021$ \\
Universitas Pembangunan Panca Budi & C & 2016 & $02-06-2021$ \\
Universitas Sumatera Utara & A & 2017 & $10-01-2022$ \\
\hline
\end{tabular}

Source: www.banpt.or.id, accessed on May 3, 2018.

The table above shows Universitas Harapan Medan accredited with $\mathrm{C}$ for its postgraduate program in management. This indicates its quality of education had not been recognized as good among other universities. Thus, it might be the cause of the decline.

The decision to pursue education to a higher level is also inseparable from the financial aspect. Education will be difficult to achieve if the expenses imposed are costly. This is consistent with previous research conducted by Jelena Gajić (2012) which stated that "Price is also a good indicator of quality and it plays an important role when creating the image of a higher education institution. Consequently, it is considered at the same time as a significant element in the strategic planning of an educational institution when deciding which faculty to choose." 
Table 3. Cost of Education of Master in Management Programs in Medan

\begin{tabular}{lll}
\hline \multirow{2}{*}{ Higher Education } & \multicolumn{2}{c}{ Cost of Education (per Semester) } \\
\cline { 2 - 3 } & Regular Class & Exclusive Class \\
\hline Sekolah Tinggi Ilmu Ekonomi Informasi Teknologi dan & Rp10.000.000,- & - \\
Bisnis & Rp6.000.000,- & - \\
Universitas Darma Agung & Rp5.000.000,- & Rp6.000.000,- \\
Universitas Harapan Medan & Rp6.000.000,- & Rp7.000.000,- \\
Universitas HKBP Nomensen & $R p 5.000 .000,-$ & Rp6.250.000,- \\
Universitas Islam Sumatera Utara & $R p 4.500 .000,-$ & - \\
Universitas Muhammadiyah Sumatera Utara & Rp6.650.000,- & - \\
& $R p 7.650 .000,-$ & - \\
Universitas Pembangunan Panca Budi & - & $R p 6.930 .000,-$ \\
Universitas Sumatera Utara & Rp9.000.000,- & Rp15.000.000,- \\
\hline
\end{tabular}

Source: From Various Sources, 2018 (Data Processed).

The table above shows the cost of education charged by Universitas Harapan Medan to its students is still relatively affordable compared to other universities. This phenomenon should strongly support the increase in the number of students. However practically, it did not work that way.

Promotion is a communication tool that can be used to introduce the products we offer. Promotional activities cannot be ignored for today's tough competition. Research conducted by Evelyn Chiyevo Garwe (2015) also revealed the same thing that she recommended private institutions (universities) to strengthen and sharpen marketing and promotion strategies to get as many people (students) as possible because they were very important in helping prospective students in making decisions. This was due to their preferences for those decisions influenced by social environment and marketing.

The issues related to promotion were the lack of intensity of promotion by the faculty that evidenced by the absence of promotion teams that were responsible to specifically introduce the program to both public and undergraduate students, advertisements that were considered lacking in breakthroughs, and the forms of promotion that seemed so-so and very conventional. Conventional promotional activities applied were such as distributing brochures, advertising on billboards, newspapers, and brief speeches promoting that postgraduate program during commencement.

Based on the description above, it can be concluded that Accreditation, Cost of Education, and Promotion are important factors that influence the prospective students in making Decisions to pursue their Masters in Management at Universitas Harapan Medan. Hence, the 
study is conducted to evaluate four primary relationships below:

1) To examine the influence of Accreditation on the Decision of Prospective Students.

2) To examine the influence of Cost of Education on the Decision of Prospective Students.

3) To examine the influence of Promotion on the Decision of Prospective Students.

4) To examine the influence of Accreditation, Cost of Education, and Promotion simultaneously on the Decision of Prospective Students.

\section{Literature Review}

\subsection{Consumer Decision}

Consumer decision making is a process of interaction between affective, cognitive, and behavioral attitudes towards environmental factors in which humans exchange in all aspects of their lives. Affective attitude reflects the belief, cognitive attitude reflects understanding, while behavioral attitude reflects real action. The decision to buy or not is a part of inseparable elements of a consumer called "behavior" in which this refers to tangible and visible action (Peter-Olson in Nitisusastro, 2013:195). Consumer decision is the final step of a series of processes that occur in consumer behavior (Nitisusastro, 2013:194).

\subsection{Accreditation}

Accreditation is the recognition for educational institutions provided by a particular authorized board after being assessed and meeting certain requirements or criteria (www.kbbi.web.id). Accreditation is the recognition for universities or study programs that show the institutions or study programs are implementing educational programs and the quality of graduates it produces has met the standards set by the National Accreditation Board for Higher Education (BAN-PT). Accreditation by BAN-PT is done by assessing the process and performance as well as the relationship between objectives, inputs, processes, and outputs of the institutions or study programs, in which it is the responsibility of the higher educational institutions or study programs (BAN-PT Buku I Naskah Akademik, 2010:ii). Badan Akreditasi Nasional Perguruan Tinggi (BAN-PT) is the only accreditation body that has the authority from the Ministry of Research, Technology, and Higher Education of the Republic of Indonesia to improve the quality of higher education, introduce and disseminate the "New Paradigm in Managing Higher Education", as well as improve relevance, academic atmosphere, institutional management, efficiency and sustainability of higher education.

\subsection{Cost of Education}

Price is the amount billed for a product or service. More broadly, price is the sum of all the values given by customers to benefit from owning or using a product or service (Kotler and Armstrong, 2008:345). Price in the broadest sense is not only the amount of money paid to the seller to get goods purchased. But it also includes things instead of money, such as time, effort to figure it out, psychological risk, additional expenditure for guarantee. Based on the consumer's perspective, price is something to sacrifice to get goods and/or services. However, 


\section{Macrothink}

Journal of Asian Development

ISSN 2377-9594 2019, Vol. 5, No. 3

this sacrifice is not solely in the form of price, it still contains several other elements such as time sacrifice, cost sacrifice, energy sacrifice, and sacrifice of feelings devoted to obtaining information about the products of goods and/or services needed until the buying decision made (Supranto, 2010:67).

\subsection{Promotion}

Promotion is defined as persuading communication and communication strategies including a habit of mixing advertisement, personal sales, sales promotion, public relations, and direct marketers (sending direct mail, electronic mail, and telemarketing) (Supranto, 2010:68). Promotion is one of the variables in the marketing mix that is very important to be carried out by companies in marketing service products. Promotional activities not only function as a communication tool between companies and consumers but also as a tool to influence consumers in the activities of buying or using services in accordance with their wants and needs. This is done with promotional tools (Lupiyoadi, 2013:178).

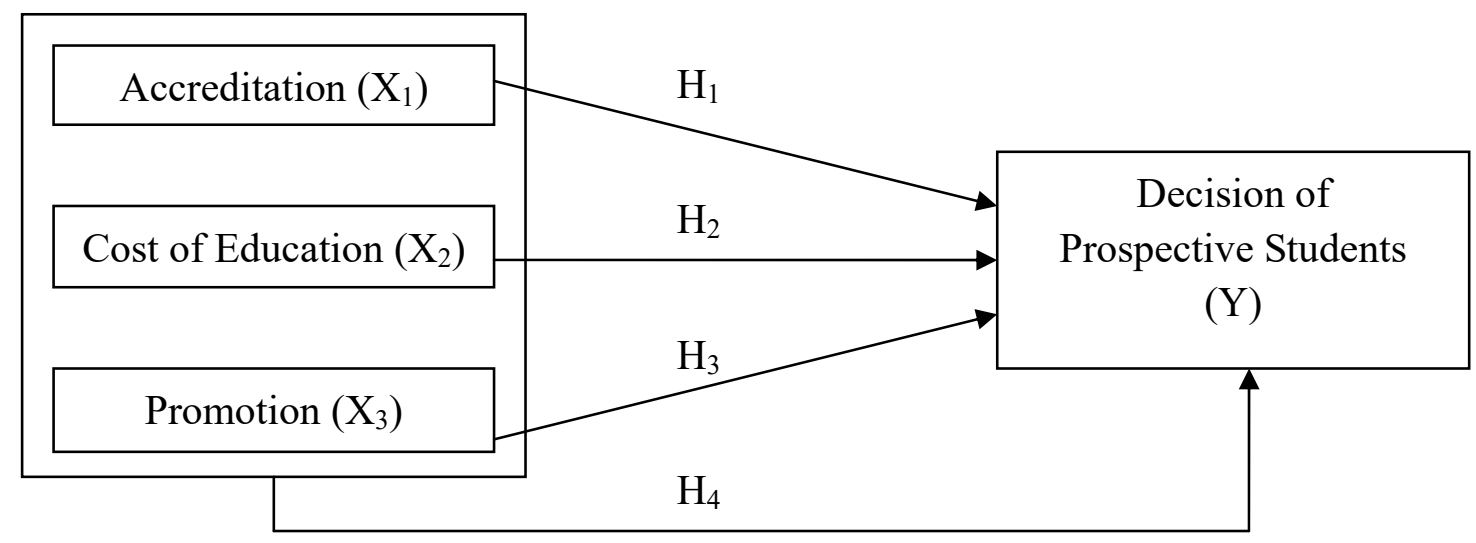

Figure 1. Conceptual Framework

\section{Research Methodology}

\subsection{Place and Period of Research}

This research was conducted at the Faculty of Business Economics of Universitas Harapan Medan, located on Jalan Imam Bonjol No. 35, Jati, Medan Maimun, North Sumatra, Indonesia. It was conducted from March to December 2018.

\subsection{Population and Sample of Research}

Population is a group of research elements, where elements are the smallest units derived from the data needed (Kuncoro, 2009:123). Population is a whole set of elements that are similar but different because of their characteristics (Suryati and Sudarso, 2016:129). The population based on the quantitative approach in this research is 227 semester VIII senior students of the undergraduate program of FEB of Universitas Harapan Medan Academic Year 2017-2018. 


\section{Macrothink}

Table 4. Population Distribution

\begin{tabular}{lll}
\hline Major & Minor & Number of Students \\
\hline Accounting & $\begin{array}{l}\text { Financial Accounting } \\
\text { Tax Accounting }\end{array}$ & 111 \\
\hline Management & $\begin{array}{l}\text { Marketing Management } \\
\text { Human Resource Management }\end{array}$ & 116 \\
\hline Total & & 227 \\
\hline
\end{tabular}

Source: FEB of Universitas Harapan Medan, 2018 (Data Processed).

Sample is a part of the number and characteristics possessed by the population (Sugiyono, 2010:80). The samples taken as respondents are 145 semester VIII senior students of the undergraduate program of FEB of Universitas Harapan Medan Academic Year 2017-2018. It was determined by using the Slovin formula. This study used a simple random sampling technique. Simple random sampling is the simplest and easiest sample selection design. The principle of this election is that every element in the population has the same opportunity to be chosen (Kuncoro, 2009:127).

\subsection{Measuring Instrument}

The measurement of each variable in this study was a Likert scale. Likert scale is used to measure the attitudes, opinions, and perceptions of a person or group of people about social phenomena. In research, this social phenomenon has been specifically determined by the researcher, which is then called the research variable. The indicators shown above will be used as the starting points for compiling instrument items either in the form of statements or questions (Sugiyono, 2010:93).

Table 5. Likert Scale

\begin{tabular}{ll}
\hline Answer of Statement & Score \\
\hline Strongly Agree (SA) & 5 \\
Agree (A) & 4 \\
Neutral (N) & 3 \\
Disagree (D) & 2 \\
Strongly Disagree (SD) & 1 \\
\hline
\end{tabular}

\subsection{Data Collection Techniques}

The data sources used in this study were primary and secondary data. Primary data is data 
obtained directly from respondents or authorized parties to provide related information through interviews and questionnaires. Secondary data is primary data that has been further processed and presented by both primary data collectors and/or other parties. In other words, secondary data is data that supports primary data obtained from documentation review in order to support research. Data collection techniques used were as follows:

1. Questionnaire is a data collection technique by asking questions to undergraduate students of FEB of Universitas Harapan Medan about the variables examined in this research.

2. Interview is a data and information collection technique which holds a face-to-face question and answer session directly with the involved parties. They are the authorized administrators and staff of the university.

3. Document review is one of the data collection techniques carried out by examining documents and written material of Universitas Harapan Medan).

\subsection{Validity and Reliability}

Validity test aims to measure whether a questionnaire is valid or not. The minimum requirement must be achieved is $r=0.2787$. Therefore the items in the instrument are invalid if the correlation of each statement is less than 0.2787 (Sugiyono, 2010:134). In this study, validity test was applied to 35 students out of samples and conducted at a similar institution. Reliability test aims to see whether the instrument used (questionnaire) shows consistency in measuring the same indication. Reliability can be determined right after the items are valid. A variable is considered reliable if it gives a Cronbach alpha value $(\alpha)>0.6$.

\subsection{Classical Assumption Tests}

Before testing the hypotheses, it will first be tested the occurrence of deviations from classical assumptions. There are several tests to do namely normality test, multicollinearity test, and heteroscedasticity test.

\subsubsection{Normality Test}

The normality test is used to find out whether in the dependent variable regression model, the independent variable, or both have a normal distribution or not. A good regression model is a normally-distributed regression model. Instead of histograms and P-Plots, normality tests can be done by using the Kolmogorov-Smirnov (goodness of fit) test. In the Kolmogorov-Smirnov test, we compare the value of significance (sig.) to the value of $\alpha(5 \%)$. It is distributed normally if the significance value (probability) is $>0.05$.

\subsubsection{Multicollinearity Test}

Multicollinearity test is set for multiple regression analysis consisting of two or more independent variables. It is used to measure the closeness of the relationship between independent variables through the magnitude of the correlation coefficients. One of the methods for diagnosing the presence of multicollinearity is by analyzing the value of Variance Inflation Factor (VIF) and Tolerance. There is no multicollinearity if VIF is $<10$ 
and Tolerance is $>0.1$.

\subsubsection{Heteroscedasticity Test}

Heteroscedasticity test aims to find out whether there is an inequality of variation of residuals from observation to another observation in a regression model. Homoscedasticity is the ideal regression model as it shows the variation of residuals from observation to other observations is permanent.

\subsection{Hypothesis Testing}

\subsubsection{Multiple Linear Regression Analysis}

The method of linear regression analysis serves to determine the effect/relationship between the independent variable and the dependent variable. The researcher used the help of SPSS to obtain more directed results. The formula for calculating multiple regression equation is $\mathrm{Y}$ $=\mathrm{a}+\mathrm{b}_{1} \mathrm{X}_{1}+\mathrm{b}_{2} \mathrm{X}_{2}+\mathrm{b}_{3} \mathrm{X}_{3}+\mathrm{e}$

\subsection{2 t Test}

The $t$ test aims to determine the influence of the independent variables on the dependent variable partially. To find out if the proposed hypotheses are accepted, we need to compare the calculated $t$ value against the $t$ value obtained from $t$ distribution table. Ha is accepted and $\mathrm{H}_{0}$ is rejected if calculated $\mathrm{t}$ value $>\mathrm{t}$ value obtained from $\mathrm{t}$ distribution table at $\alpha=5 \%$ and vice versa.

\subsubsection{F Test}

This test aims to determine if all the independent variables examined in the model have a simultaneous influence on the dependent variable. To find out if the proposed hypothesis is accepted, we need to compare the calculated $\mathrm{F}$ value against the $\mathrm{F}$ value obtained from the $\mathrm{F}$ distribution table. $\mathrm{Ha}$ is accepted and $\mathrm{H}_{0}$ is rejected if calculated $\mathrm{F}$ value $>\mathrm{F}$ value obtained from $\mathrm{F}$ distribution table at $\alpha=5 \%$ and vice versa.

\subsubsection{Determination Test $\left(\mathrm{R}^{2}\right)$}

According to Kuncoro (2009:240), the coefficient of determination is a tool that measures how far the ability of the model (independent variables) in explaining variations in the dependent variable. This coefficient of determination $\left(R^{2}\right)$ ranges from zero to one $\left(0 \leq R^{2} \leq\right.$ 1 ), where the higher $R^{2}$ (close to 1 ) means that the independent variables provide almost all the information needed to predict the dependent variable and if $\mathrm{R}^{2}=0$ indicates the independent variable as a whole cannot explain the dependent variable.

\section{Result and Discussion}

\subsection{Validity and Reliability}

In the validity test, items of all variables were declared valid because they met the predetermined requirement. While in the reliability test, they were declared totally reliable because they met the predetermined requirement as well. All items got Cronbach's Alpha 
$(\alpha)>0.6$.

Table 6. Results of Validity (Out of Samples) and Reliability

\begin{tabular}{|c|c|c|c|c|c|c|c|c|c|c|c|}
\hline \multirow{2}{*}{ Variable } & \multicolumn{10}{|c|}{ Validity } & \multirow{2}{*}{ Reliability } \\
\hline & 1 & 2 & 3 & 4 & 5 & 6 & 7 & 8 & 9 & 10 & \\
\hline $\mathrm{X}_{1}$ & .862 & .861 & .857 & .862 & .861 & .888 & .871 & .873 & .875 & .875 & .880 \\
\hline $\mathrm{X}_{2}$ & .910 & .906 & .903 & .901 & .891 & .908 & .903 & .897 & .909 & .901 & .912 \\
\hline $\mathrm{X}_{3}$ & .907 & .896 & .901 & .901 & .908 & .902 & 911 & .904 & .905 & .906 & .913 \\
\hline Y & .887 & .888 & .878 & .871 & .874 & .866 & .871 & .876 & .875 & .868 & .870 \\
\hline
\end{tabular}

\subsection{Classical Assumption Tests}

\subsubsection{Normality Test}

Based on the SPSS output, the value of Asymp. Sig. (2-tailed) was 0.064. This number was greater than 0.05 . So it could be concluded that the data were normally distributed.

\subsubsection{Multicollinearity Test}

The values of VIF for Accreditation, Cost of Education, and Promotion were 1.531, 1.615, and 1.799 respectively. Besides, the values of Tolerance were $0.653,0.619$ and 0.556 respectively. The VIFs obtained were $<10$ and the Tolerance was $>0.1$, so it meant no multicollinearity problems happened.

\subsubsection{Heteroscedasticity Test}

From the Scatterplot chart, the dots spread randomly or did not form a certain pattern. This meant there was no heteroscedasticity in this regression model.

\subsection{Hypothesis Testing}

4.3.1 Multiple Linear Regression Analysis

$$
\mathrm{Y}=3.882+0.294 \mathrm{X}_{1}+0.027 \mathrm{X}_{2}+0.584 \mathrm{X}_{3}
$$

The value of $\mathrm{bX}_{1}$ indicated if Accreditation was increased, then the Decision of Prospective Students would increase by 0.294 and vice versa. The value of $\mathrm{bX}_{2}$ indicated if the Cost of Education was increased, then the Decision of Prospective Students would increase by 0.027 and vice versa. The value of $\mathrm{bX}_{3}$ indicated if Promotion was increased, then the Decision of Prospective Students would increase by 0.584 and vice versa. 


\subsection{2 $\mathrm{t}$ Test}

The $\mathrm{t}$ value obtained from $\mathrm{t}$ distribution table was 1.97693 . The $\mathrm{t}$ values calculated were $\mathrm{X}_{1}=$ 4.479 and $\mathrm{X}_{3}=8.436$, it meant $\mathrm{H}_{1}$ and $\mathrm{H}_{3}$ were accepted and $\mathrm{H}_{0}$ was rejected. While Cost of Education got $\mathrm{X}_{2}=0.395$, it meant $\mathrm{H}_{0}$ was accepted and $\mathrm{H}_{2}$ was rejected

\subsubsection{F Test}

The value of $\mathrm{F}$ calculated (79.402) $>\mathrm{F}_{\text {table }}$ (2.67). Then $\mathrm{H}_{0}$ was rejected and $\mathrm{H}_{4}$ was accepted. It meant that $\mathrm{Y}$ multiple linear equation of $\mathrm{X}_{1}, \mathrm{X}_{2}$, and $\mathrm{X}_{3}$ was real. It meant that Accreditation, Cost of Education, and Promotion simultaneously had a significant influence on the Decision of Prospective Students at Universitas Harapan Medan.

\subsubsection{Determination Test $\left(\mathrm{R}^{2}\right)$}

The determinant value $\left(\mathrm{R}^{2}\right)$ was $0.628(62.8 \%)$. Thus it could be concluded that Accreditation, Cost of Education, and Promotion had a contribution of $62.8 \%$ to the Decision of Prospective Students to pursue postgraduate studies at Universitas Harapan Medan. The remaining 37.2\% were determined by other factors not examined, such as social, cultural, personal, psychological factors, etc.

\section{Conclusion}

After conducting this research, some conclusions can be drawn as follows:

1. Accreditation partially had a positive and significant influence on the Decision of Prospective Students to pursue postgraduate studies. It meant $\mathrm{H}_{1}$ was accepted. This phenomenon explained prospective students in the postgraduate program of FEB of Universitas Harapan Medan paid great attention to the quality of education offered through an accreditation label given by authorized institution (BAN-PT).

2. Cost of Educational partially had a positive and insignificant influence on the Decision of Prospective Students to pursue postgraduate studies. It meant $\mathrm{H}_{2}$ was rejected. This phenomenon showed prospective students had a perception that universities that have only affordable tuition fees as an attraction were less preferred if not supported by other factors. These other factors include good education quality, intense promotion, and excellent academic and managerial service. The cost of education which is supported by good quality education will greatly help in increasing the number of students.

3. Promotion partially had a positive and significant influence on the Decision of Prospective Students to pursue postgraduate studies. It meant $\mathrm{H}_{3}$ was accepted. This phenomenon confirmed that promotion was the main gate of communication in introducing a product (service). If the promotional activities were greatly intensified, then prospective students would be more familiar with the product (service) in more detail and the possibility to use the product (to register) would also be greater.

4. There was a positive and significant influence of Accreditation, Cost of Education, and Promotion simultaneously on the Decision of Prospective Students to pursue 
postgraduate studies. It meant $\mathrm{H}_{4}$ was accepted.

Based on the conclusions described above, there are several points to suggest as follows:

1. BOM and some other universities should pay more attention and continuously strive to improve the accreditation of the study program from $\mathrm{C}$ to better ranking (B and/or A) because accreditation is proven to be an important consideration for prospective students to pursue their studies in the postgraduate program of FEB of Unhar. The number of prospective students who will enroll in the master's program is going to certainly increase significantly if it has better accreditation (B and/or A).

2. BOM and some other universities are expected to be able to provide inexpensive (affordable) as well as excellent quality education. Remembering the cost of education is relatively high nowadays, the implementation of excellent quality education with relatively affordable tuition fees will stimulate an increase in the number of prospective students enrolled. It will be the strength not only for Universitas Harapan Medan but also for other universities if it is executed properly.

3. BOM should consider the brand new promotional concepts. Conventional promotion must be balanced with the creative and innovative one because instead of requiring a large budget, it is considered to be out of date. There are lots of innovative ways of promoting, for instance: letting students themselves introduce their campus by organizing interest-and-talent-oriented activities such as cinematographic video, Vlog, and Blog making competitions about its master's program. Instead of saving on the promotional budget, it is more effective because the direct share will be done on social media. The second way is Unhar shall also create its own social media accounts like Instagram, Facebook, as well as YouTube and then upload interesting photos and videos regarding programs offered on a regular basis. It is very helpful in building a positive perception of Unhar. The third way is to hold in vogue events like a color run, giveaway quiz, etc. Besides, Unhar must be able to initiate mouth-to-mouth promotion among students and alumni as it does not require any budget at all.

4. BOM must be attentive to other factors not being examined like social, cultural, personal, psychological, and other factors as there are possibilities they have a large influence on the decision of prospective students to pursue postgraduate studies.

\section{Acknowledgements}

The research is conducted as one of the requirements for obtaining a Master of Management (M.M.) in the Universitas Harapan Medan. Thanks to Prof. Dr. Abdul Muin Sibue, M.Pd. and Dr. Tapi Rondang Ni Bulan, Universitas Harapan Medan.

\section{References}

Anam, S., \& Haque, M. (2015). Ranking of the Determinants Affecting Students' Attitude of a Higher Education Institution: Application of AHP. International Journal of Human Resource Studies, 5(2), 1-9. http://dx.doi.org/10.5296/ijhrs.v5i2.6040 
Badan Akreditasi Nasional Perguruan Tinggi. (2010). Buku V Pedoman Penilaian Instrumen Akreditasi. Jakarta: BAN-PT.

Badan Akreditasi Nasional Perguruan Tinggi. (2016). Direktori Hasil Akreditasi Program Studi. [Online] Available: https://banpt.or.id/direktori/prodi/pencarian_prodi (May 3, 2018).

Badan Pengembangan dan Pembinaan Bahasa. (2012-2018). Kamus Besar Bahasa Indonesia. [Online] Available: https://kbbi.web.id/akreditasi (May 3, 2018).

Gajić, J. (2012). Importance of Marketing Mix in Higher Education Institutions. Singidunum Journal, 9(1), 29-41. http://dx.doi.org/10.5937/sjas1201029G

Haron, H., Hamid, N. A. A., Jamaludin, J., \& Azan, K. N. K. (2017). Students' Decision Factors in Choosing Private Higher Education Institutions. International Journal of Academic Research in Business and Social Sciences, 7(11), 1372-1382. http://dx.doi.org/10.6007/IJARBSS/v7-i11/3576

Kamal, B., \& dan Rahmadiane, G. D. (2017). Pengaruh Persepsi, Akreditasi Prodi, dan Promosi terhadap Keputusan Memilih Program Studi Akuntansi pada Politeknik Harapan Bersama. Jurnal Inspirasi Bisnis dan Manajemen, 1(2), 145-158. http://jurnal.unswagati.ac.id/index.php/jibm

Kotler, \& Armstrong. (2008). Prinsip-Prinsip Pemasaran. Jilid 1. Edisi Kedua Belas. Jakarta: Penerbit Erlangga.

Kotler, P. (2003). International Edition Marketing Management. Eleventh Edition. Singapore: Prentice Hall.

Kristiani, N. (2016). Faktor-Faktor yang Mempengaruhi Keputusan Orang Tua Siswa Memilih SD Kasatriyan Surakarta. Jurnal Manajemen Maranatha, 16(1), 91-118. https:/www.neliti.com/id/publications/115673/faktor-faktor-yang-mempengaruhi-keputusanorang-tua-siswa-memilih-sd-kasatriyan

Kuncoro, M. (2009). Metode Riset untuk Bisnis dan Ekonomi. Edisi Ketiga. Jakarta: Penerbit Erlangga.

Kurniawati, D. (2013). Pengaruh Strategi Bauran Pemasaran terhadap Keputusan Mahasiswa Memilih Universitas Katolik Widya Mandala Madiun. Jurnal Ilmiah Widya Warta, 37(01), 65-80. http://portal.widyamandala.ac.id/jurnal/index.php/warta/article/view/137

Kusumawati, A. (2013). A Qualitative Study of the Factors Influencing Students' Choice: The Case of Public University in Indonesia. Textroad Publication: Journal of Basic and Applied Scientific Research, 3(1), 314-327. https://pdfs.semanticscholar.org/9265/b6d6fc127de2961e5e8bfb475dc8b7c13b43.pdf

Lovelock, C., Wirtz, J., \& Keh, H. T. (2002). Services Marketing in Asia: Managing People, Technology, and Strategy. $4^{\text {th }}$ Edition. Singapore: Prentice Hall.

Moleong, L. J. (2002). Metodologi Penelitian Kualitatif. Bandung: Remaja Rosdakarya. 
Mulyati, Y., Mailinarti, dan Masruri. (2016). Analisis Faktor-Faktor yang Mempengaruhi Keputusan Mahasiswa dalam Memilih Perguruan Tinggi Swasta di Kota Padang. Jurnal Ekonomi dan Bisnis Dharma Andalas, 18(1), 201-228. http://ojs.unidha.ac.id/index.php/edb_dharmaandalas/article/view/22

Nitisusastro, M. (2013). Perilaku Konsumen dalam Perspektif Kewirausahaan. Bandung: Penerbit Alfabeta.

Nugroho, C. S. (2010). Analisis Pengaruh Pencitraan, Promosi, dan Kualitas Pelayanan terhadap Minat Kuliah di Diploma III Fakultas Ekonomi Universitas Diponegoro. Semarang: Universitas Diponegoro.

Pascasarjana. (2018). Petunjuk Penulisan Usulan Penelitian dan Tesis. Pascasarjana. Medan. Universitas Harapan Medan.

Purhantara, W. (2010). Metode Penelitian Kualitatif untuk Bisnis. Yogyakarta: Graha Ilmu.

Sia, J. K. M. (2011). Post-Secondary Students' Behaviour in the College Choice Decision. IBIMA Publishing: Journal of Marketing Research and Case Studies, 2011(2011), 1-15. http://dx.doi.org/10.5171/2011.440964

Sugiono. (2010). Metode Penelitian Kuantitatif Kualitatif dan R\&D. Bandung: Penerbit Alfabeta.

Suliyanto (2009). Metode Riset Bisnis. Yogyakarta: Penerbit Andi.

Supranto, J. (2010). Statistik Teori dan Aplikasi. Jakarta: Penerbit UI Press.

Suryati, L., \& dan Sudarso, A. (2016). Metodologi Penelitian (Petunjuk Praktis untuk Penyusunan Skripsi Ekonomi dan Tesis Magister Manajemen). Yogyakarta. Deepublish.

Wahyono, S. A., dan Susilawati. (2016). Pengaruh Bauran Promosi terhadap Kepercayaan dan Dampaknya terhadap Keputusan Mahasiswa Memilih Kuliah (Studi Kasus Politeknik LPKIA Kota Bandung). Jurnal Indonesia Membangun, 2(1). Diambil dari http://jurnal-inaba.hol.es/index.php/JIM/article/view/84

Wikipedia. (2018). Definisi Akreditasi. [Online] Available https://id.wikipedia.org/wiki/Akreditasi (May 3, 2018).

Wulandini, P., dan Saputra, R. (2017). Pengambilan Keputusan Mahasiswa dalam Memilih Perguruan Tinggi Swasta di Pekan Baru. Jurnal Sains Sosial dan Humaniora, 1(2): 93-103.

Zain, O. M., Jan, M. T., and Ibrahim, A.B. (2013). Factors Influencing Students' Decisions in Choosing Private Institutions of Higher Education in Malaysia: A Structural Equation Modelling Approach. Asian Academy of Management Journal, 18(1), 75-90. https://www.academia.edu/2479211/factors_influencing_students_decisions_in_choosing_pri vate_institutions_of_higher_education_in_malaysia_a_structural_equation_modeling_approa ch 


\section{Glossary}

BAN-PT : Badan Akreditasi Nasional Perguruan Tinggi

BOM : Board of Management

FEB : Faculty of Business Economics

SPSS : Statistics Product and Service Solution

Unhar : Universitas Harapan

\section{Appendix}

Appendix 1. Output of SPSS

\section{Copyright Disclaimer}

Copyright for this article is retained by the author(s), with first publication rights granted to the journal.

This is an open-access article distributed under the terms and conditions of the Creative Commons Attribution license (http://creativecommons.org/licenses/by/4.0/). 